\title{
INCURSÕES MILITARES UNILATERAIS EM SOLO ESTRANGEIRO E A SUA LEGITIMIDADE: O CASO LÍBIO DE 2013
}

Dempsey Pereira Ramos JúnIOR

Doutorando em Direito pela Universidade de Coimbra (Portugal), Pesquisador Creditado pela Universidade de Bergen (Noruega), Mestre em Direito Ambiental pela Universidade do Estado do Amazonas (UEA), professor no curso de Graduação em Direito da UEA, AM - Brasil, autor da obra "Meio Ambiente e Conceito Jurídico de Futuras Gerações", livro cujos exemplares fazem parte, no Brasil, das Bibliotecas do Supremo Tribunal Federal, do Superior Tribunal de Justiça e, no exterior, da Biblioteca do Congresso dos Estados Unidos da América. Referência na Enciclopédia de Direito Internacional Público, do Instituto Max Planck (Alemanha), e-mail: dempsey_junior@yahoo.com.br

Edson Damas da Silveira

Procurador de Justiça no Ministério Público do Estado de Roraima (MPRR), PósDoutor pela Universidade de Coimbra (Portugal), Mestre e Doutor em Direito Econômico e Socioambiental pela Pontifícia Universidade Católica do Paraná (PUCPR), Mestre em Antropologia pela Universidade Federal de Pernambuco (UFPE), professor em cursos de Graduação, Especialização e no Mestrado em Direito Ambiental da Universidade do Estado do Amazonas (UEA), AM - Brasil, e-mail: edsondamas@mprr.mp.br

\section{Resumo}

Em 1945, a Proclamação Truman, um ato unilateral do governo dos Estados Unidos da América, levou ao rápido surgimento de um costume internacional que, em 1958, transformou-se em uma convenção e, em 1969, foi reconhecido pela Corte Internacional de Justiça como o direito dos Estados de explorarem economicamente as suas plataformas continentais. O presente trabalho examina os efeitos da Doutrina Bush, outro ato unilateral dos EUA, no âmbito do Direito Internacional Público, em decorrência dos atentados do 11 de setembro de 2001. A pesquisa gira em torno de um caso concreto: a captura de Abu Anas al-Liby, um cidadão líbio que foi interceptado na porta de sua casa, em 05 de outubro de 2013, na cidade de Trípoli, território da Líbia. O fato aconteceu através de uma operação conjunta, que contou com a participação da CIA - Agência Central de Inteligência, do FBI - Agência Federal de Investigação e de 
militares do Comando Delta, um grupo de elite das Forças Armadas dos EUA - Estados Unidos da América, sob alegação de que o alvo tinha ligaçóes com o grupo terrorista $\mathrm{Al}$ Qaeda. Após a captura, al-Liby foi levado para interrogatório em um navio de guerra no Mediterrâneo e, depois, foi apresentado a uma Corte Federal de Nova York para ser julgado pelos atentados que, em 1998, mataram centenas de pessoas nas Embaixadas dos EUA, no Quênia e na Tanzânia. O Estado líbio negou ter concedido qualquer autorização e queixou-se de violação de soberania. $\mathrm{O}$ presente trabalho possui importância, no contexto da Península Ibérica, devido ao fato de que Portugal e Espanha estáo hoje potencialmente inseridos na agenda terrorista do Estado Islâmico do Iraque e Al-Sham (ISIS), grupo que, em 2014, declarou seu intento de recuperar todos os territórios que pertenceram ao Islão, anúncio que vem sendo considerado o mais significativo desenvolvimento do jihadismo internacional desde o 11 de setembro. A partir desses elementos, o artigo investiga se existe algum direito capaz de legitimar incursóes militares unilaterais em solo estrangeiro. Como resultado, pode-se dizer que está em curso uma formação acelerada de costume internacional.

\section{Palavras-chave}

Soberania; Captura de civis; Costume instantâneo; Direito internacional.

\section{Abstract}

In 1945, the Truman Proclamation, a government unilateral act of the United States, led to the rapid emergence of an international custom that in 1958 turned into a convention and in 1969 was recognized by the International Court of Justice as the right of states to economically exploit their continental shelves. This paper examines the effects of the Bush Doctrine, another US unilateral act, under public international law, due to the attacks of 11th September 2001. This research centers on a specific case: the capture of Abu Anas al -Liby, a Libyan citizen who was stopped at the door of his home in October 5th, 2013, in the city of Tripoli, the Libyan territory. It happened in a joint operation, which saw the participation of the CIA - Central Intelligence Agency, the FBI - Federal Bureau of Investigation and the Delta Force soldiers, a group of elite US military - United States, on the grounds that the targeted one had links with the terrorist group Al Qaeda. After his capture, al-Liby was taken in for questioning on a warship in the Mediterranean sea and then was presented before a Federal Court of New York to stand trial for the attacks that in 1998 killed hundreds of people in US Embassies, in Kenya and Tanzania. The Libyan state denied having granted any authorization and complained of violation of sovereignty. This work has importance in the context of the Iberian Peninsula, due to the fact that Portugal and Spain are now potentially inserted into the terrorist agenda of the Islamic State of Iraq and al-Sham (ISIS), a group that, in 2014, declared his intent to 
recover all the territories that belonged to Islam, announcement that has been considered the most significant development of international jihadism since 11th September. From these elements, the paper investigates whether there is any right capable of legitimizing unilateral military raids on foreign soil. As a result, it can be said that there is an ongoing accelerated formation of international custom.

\section{Key words}

Sovereignty; Capturing civilians; Instant custom; International law.

\section{Introdução}

O presente trabalho está estruturado a partir da análise de um caso concreto ocorrido na Líbia, em 05 de outubro de 2013, quando o cidadáo líbio Abu Anas al-Liby foi capturado à porta de sua casa, dentro do próprio território líbio, através de uma operação conjunta que contou com a participação de agentes norte-americanos da CIA - Agência Central de Inteligência, do FBI - Agência Federal de Investigação e de militares do Comando Delta, um grupo de elite das Forças Armadas dos EUA - Estados Unidos da América, sob alegação de que al-Liby tinha envolvimento com a organização terrorista Al Qaeda. Embora o caso seja aparentemente uma situação simples de ser examinada, do ponto de vista jurídico, cuja análise poderia limitar-se ao exame das convençóes internacionais vigentes à data do fato e, com base em tais textos jurídicos, chegar-se a uma conclusão sobre a legalidade ou ilegalidade da operação; há de se esclarecer que a captura do mencionado cidadáo líbio por forças militares estrangeiras traz à tona questóes muito mais diversificadas e complexas do que pode parecer.

A importância do trabalho deve-se ao fato do tema inserir-se em um contexto mais amplo de questóes geopolíticas que afetam, de modo direto, os interesses nacionais e territoriais de Portugal e Espanha. Em 2014, a organização terrorista Estado Islâmico do Iraque e Al-Sham (ISIS), que hoje controla um território que se estende desde o Iraque até a Síria, lançou um plano de cinco anos, cujo objetivo é retomar até 2020 os antigos territórios que estiveram sob governo muçulmano na Península Ibérica, entre os anos de 711 a 1492, além dos territórios situados no norte da África, dos territórios balcânicos do sul da Europa, de todo o Oriente Médio até partes mais ocidentais da China. A intenção do ISIS é "restaurar" o antigo Império Otomano e, a partir de uma redefinição do mapa geopolítico contemporâneo, estabelecer um Califado cuja extensão abrangerá desde a Europa mais ocidental, sua Península Ibérica, até partes da China. Este anúncio vem sendo considerado o "mais significativo desenvolvimento do jihadismo internacional desde o 11 de setembro" (HALL, 2014). Como parte dos esforços mundiais contra essa ameaça, o Ministro dos Negócios Estrangeiros de Portugal, Rui Machete, confirmou em 
Washington, no dia 21 de abril de 2015, que 30 militares portugueses serão enviados ao Iraque para um trabalho de formação, preparação e capacitação do Exército iraquiano (DN, 2015).

Atualmente, o ISIS controla sozinho mais territórios do que Israel e Líbano juntos, sua área de controle já abrange $1 / 3$ do Iraque (ROSEN, 2014). Só na região de Aleppo, na Síria, o ISIS controla uma área de $10 \mathrm{mil} \mathrm{km} \mathrm{km}^{2}$, maior do que 48 países no mundo (CARIS \& REYNOLDS, 2014, p. 27). Dentre suas fontes de financiamento, estimase que o ISIS arrecada algo em torno de US\$ 1 milhão a US\$ 2 milhóes por dia, com a venda de petróleo contrabandeado para a Turquia. De acordo com Matthew Levitt, Diretor do Programa de Inteligência e Contraterrorismo, do Instituto para Política do Oriente Próximo, o ISIS é o grupo terrorista com a melhor base de financiamento jamais vista. O grupo nasceu a partir de bandidos de um Iraque quebrado e, na sua raiz, tem a atividade criminosa como método de ação. Em qualquer lugar onde o ISIS se estabelece, não existem limites, leis ou quaisquer obstáculos capazes de controlar suas atividades. $\mathrm{Na}$ cidade de Mosul, o ISIS saqueou o Banco Central do Iraque e estima-se que apoderou-se de centenas de milhóes de dólares. Em todas as áreas onde atua, o grupo está tributando as pessoas e as atividades econômicas locais, o que intensifica ainda mais suas fontes de suporte financeiro (BRONSTEIN \& GRIFFIN, 2014).

Como um grupo que, no início da sua formação, era relativamente pequeno, uma antiga filial da $\mathrm{Al}$ Qaeda, constituída por poucos milhares de radicais islâmicos, conseguiu vencer o Exército de 350 mil homens do Iraque, treinado durante dez anos pelos EUA? Para o professor do Massachusetts Institute of Technology - MIT, Noam Chomsky, a raiz do colapso do Exército iraquiano está na violência dos EUA que, ao atacar uma sociedade muito vulnerável - o Iraque, deu origem a conflitos sectários que não existiam antes. Com a chegada do ISIS na região, os generais iraquianos foram os primeiros a fugir. E os soldados, que não sabiam o que fazer, fugiram em seguida (CHOMSKY, 2015). Entretanto, para o jornalista Patrick Cockburn, correspondente do Financial Times no Oriente Médio desde 1979, e que atualmente escreve para o The Independent, o motivo da erosão do Exército iraquiano foi um só: a corrupção no Iraque (COCKBURN, 2014).

A exposição desses fatos, na parte introdutória do presente trabalho, tem por objetivo enquadrar o tema, no contexto geral da atual geopolítica internacional. De modo mais específico, o objetivo desta introdução é demonstrar a conexão entre o caso líbio de 2013, objeto central deste paper, e a ascensão do denominado Estado Islâmico do Iraque e Al-Sham (ISIS). Ao lado das preocupaçóes mundiais que o ISIS suscita, com todas as medidas governamentais que vêm sendo elaboradas para combatê-lo, o tema é de especial interesse para os países da Península Ibérica - Portugal e Espanha, na medida em que este paper busca analisar a legitimidade das incursóes militares em solo estrangeiro, levadas a cabo de modo unilateral pelas Forças Armadas de Estados integrantes da ONU. Assim, 
será que a Espanha, cuja cidade de Madrid já foi alvo de terrorismo, em 2004; e Portugal, hoje um Estado potencialmente inserido na agenda terrorista do ISIS, estariam preparados para receberem nos seus territórios, e aceitarem como ato legítimo, intervençóes militares unilaterais a pretexto do combate ao terrorismo? O caso líbio de 2013 pode trazer luz para estas questóes.

Dois dias após a captura de al-Liby, o Departamento de Estado norte-americano e Casa Branca, através do Presidente Barack Obama, ofereceram conferências de imprensa, ocasião em que as principais perguntas levantadas pelos jornalistas foram justamente sobre a legalidade da operação, especialmente sob o âmbito do Direito Internacional. Neste aspecto, a principal dificuldade de análise girava em torno do conceito de conflito armado, já que as convençôes internacionais que cuidam da regulação do uso da força militar em território estrangeiro, por terem sido elaboradas nos anos de 1940 e 1950, partiam do pressuposto de que conflito armado envolvia a guerra, declarada ou náo, entre dois ou mais "Estados" e suas respectivas forças militares. Entretanto, a captura de al-Liby ocorreu em um contexto de ausência de guerra entre a Líbia e os EUA. Além disso, o status pessoal de al-Liby era de um cidadão, agente privado de natureza civil, não integrante do Exército líbio. Acrescente-se, ainda, que as convençôes internacionais vigentes à época da operação, permitiam uma interpretação dúbia sobre o assunto. Tudo isso leva à primeira dificuldade, relativa ao enquadramento da operação, se esta deveria ser regulada pelas normas jurídicas do Direito de Guerra ou não. A segunda dificuldade refere-se à hierarquia de fontes no Direito Internacional ou, como preferem alguns estudiosos, uma hierarquia dos possíveis resultados obtidos em um processo hermenêutico. O Estatuto da Corte Internacional de Justiça coloca as convenções no centro das fontes jurídicas passíveis de dar amparo às suas decisóes. Entretanto, convençóes demoram a formar-se e o terrorismo, por sua vez, exige ações e soluções rápidas, dinâmicas.

Além disso, o caso envolve aspectos bem mais amplos do que apenas a análise de sua legalidade. Envolve, por exemplo, questóes relacionadas à legitimidade da captura de al-Liby, conceito que não é necessariamente sinônimo de legalidade. Abrange ainda as noçóes de justo e injusto, pois a operação foi realizada com o objetivo de levar al-Liby à justiça. Aliás, o objetivo declarado dos EUA era o de fazer justiça aos cidadãos norte-americanos mortos nos atentados à bomba, cuja autoria foi imputada àquele cidadáo líbio; a busca por justiça foi o argumento mais enfatizado por todas as autoridades norte-americanas para legitimar a operaçáo. $\mathrm{O}$ conceito de justiça, embora relacionado com o de legalidade e o de legitimidade, não se confunde, todavia, com estas categorias e, portanto, merece uma análise mais profunda que, por razóes de tempo e de limite de conteúdo do presente paper, não é possível fazer aqui.

Há ainda a possibilidade de se identificar, diante dos detalhes do caso, o surgimento de um possível protocostume internacional instantâneo, que pode estar em sua fase 
embrionária de formação e que, futuramente, pode vir a cristalizar-se de modo codificado, e mais formal, sob a roupagem de uma convenção internacional escrita, no sentido do Direito Internacional vir a autorizar, sem dúvidas hermenêuticas, o uso unilateral da força militar de um Estado em territórios estrangeiros, sempre que for invocado como motivo o combate ao terrorismo.

Diante dessa amplitude de questóes que o caso suscita, optou-se por apresentar uma visão panorâmica do assunto, com delimitação circunscrita aos argumentos jurídicos, tanto a favor como contra aquela operação militar. O objetivo primordial é apontar ou, ao menos, sinalizar onde está o direito neste caso. Em outras palavras, que tipo de direito autoriza ou pró́be a conduta unilateral dos Estados Unidos da América de capturar um civil em território estrangeiro e, em seguida, levá-lo para interrogatório em um navio de guerra no Mediterrâneo e, ao final, apresentar esse cidadão a uma Corte Federal em Nova York? Sua lei doméstica, as convenções internacionais, o costume internacional, a jurisprudência? Ou será que a operação baseou-se juridicamente nas chamadas fontes materiais do direito, por exemplo, o poder financeiro de Wall Street; a influência política e diplomática da Casa Branca perante o Conselho de Segurança da ONU; ou o puro e simples poder bélico de suas Forças Armadas?

As posiçóes encontradas são conflitantes. Como hipótese de trabalho, este paper aponta, em resposta aos questionamentos acima, para um quadro complexo em que múltiplos fatores (econômicos, geopolíticos, sociais e jurídicos) se entrecruzam, de modo que a questão da legitimidade e da justiça da captura de al-Liby, embora não repouse com exatidão em textos de lei e de convençôes internacionais, por outro lado não chegou a gerar reaçôes extremas, nem objeçôes sérias por parte da comunidade internacional, notadamente manifestaçóes oficiais de repúdio por parte dos Estados, das organizaçóes intergovernamentais ou de qualquer órgão da ONU. A única exceção foi o Estado líbio que alegou não ter autorizado a entrada dos EUA, em seu território, mas mesmo assim afirmou que o fato não abalou as suas relaçóes diplomáticas com os estadunidenses.

Para cumprir os objetivos do presente trabalho, no primeiro capítulo é apresentado um resumo do caso, com base em notícias que foram divulgadas nos principais jornais de circulação mundial, bem como as opiniôes que foram colocadas nos editoriais de alguns veículos jornalísticos, onde foi possível extrair as respectivas posiçóes daquelas empresas de informação. São analisadas também as declarações oficiais prestadas por órgãos dos Estados Unidos da América, notadamente o seu Departamento de Estado, o seu Departamento de Defesa, notas para imprensa emitidas pela Casa Branca, bem como declaraçóes do seu Presidente - Sr. Barack Obama. Em seu conjunto, as manifestaçóes dos diversos órgãos do Estado norte-americano apontam, de modo geral, para a Lei de Autorização do Uso da Força Militar, uma resolução conjunta do Congresso dos Estados Unidos da América, emitida em 2001, e que tem sido por mais de uma década a base jurídica que fundamenta as incursóes militares norte-americanas em territórios estrangeiros. 
No segundo capítulo, são apresentadas as várias posições jurídico-formais sobre o caso, notadamente o conteúdo normativo extraído a partir da Carta das Naçóes Unidas (1945), da Convenção de Genebra relativa à Proteção das Pessoas Civis em Tempo de Guerra (1949), da Convenção Internacional sobre a Supressão de Atentados Terroristas com Bombas (1997), das Resoluçóes do Conselho de Segurança da ONU, n. 1368, 1373 e 1377, contra o terrorismo (2001), além do Relatório do Conselho de Direitos Humanos da ONU, sobre assassinato seletivo em território estrangeiro (2010) e, ainda, as Listas de Sançôes à Al Qaeda, mecanismo contido na Resolução n. 2083 do Conselho de Segurança da ONU (2012). No âmbito doméstico, é examinada a jurisprudência sobre captura de civis em território estrangeiro, através da leitura de decisôes adotadas pela Suprema Corte dos Estados Unidos da América e pela Suprema Corte do Reino Unido.

Ainda no segundo capítulo, são abordados alguns aspectos, não tão formais da questão, com o objetivo de trazer à tona as dimensóes mais materiais da história, da política, da economia e das relaçóes internacionais que existem em torno do caso al-Liby. Mesmo que de modo panorâmico, sem pretender esgotar a questáo, faz-se uma breve análise de um caso semelhante que ocorreu em 1960, quando agentes do Serviço Secreto de Israel capturaram o cidadão alemão Adolf Eichmann, na Argentina, sem autorização deste Estado. Secretamente, seus captores levaram-no para ser julgado por um Tribunal israelense, onde veio a ser condenado à morte e enforcado, em 1962, por crimes contra a humanidade praticados em solo alemão, durante a Segunda Guerra Mundial. A partir da comparação dos dois casos, são apontados neste tópico os argumentos de justiça e de legitimidade que foram utilizados para sustentar, ou rejeitar, referidas operaçóes. O que se observa é a utilização de critérios morais.

No último tópico, são apresentadas as conclusões obtidas após o estudo das normas, da jurisprudência e de temas típicos das relaçóes internacionais pertinentes ao objeto deste paper, onde é possível compreender o quadro de legitimidade das incursões unilaterais levadas a cabo em solo estrangeiro, por militares das Forças Armadas de um determinado Estado, a pretexto de combate ao terrorismo.

\section{O Caso Líbio de 2013}

A captura de um cidadão líbio dentro do seu próprio território, por forças especiais do Comando Delta dos Estados Unidos da América (EUA), um grupo de elite do exército norte-americano, levantou questóes importantes no âmbito do Direito Internacional. Em especial, as alegaçóes do povo e do governo da Líbia de que os EUA teriam violado a sua soberania nacional e, por outro lado, a possibilidade de formação de um costume internacional instantâneo a partir de práticas e açóes unilaterais empreendidas por um Estado.

O fato ocorreu às 6h:15 da manhã, do dia 05 de outubro de 2013, quando o cidadão Abu Anas al-Liby foi capturado em frente à casa de sua família, em Noufle’een, um 
subúrbio de Trípoli, capital da Líbia. Segundo o irmão do capturado, a esposa de al-Liby testemunhou pela janela que homens armados, com aparência de "comandos" estrangeiros, teriam sido os executores da captura. Porém, o filho de al-Liby, chamado Abdullah, disse no canal de televisão Nabir, uma estação de notícias de Trípoli, que as pessoas que levaram seu pai eram líbias, e náo americanas. $\mathrm{Na}$ data do fato, Abu Anas al-Liby tinha 49 anos; acredita-se que era um especialista em computação da organização terrorista Al Qaeda. Durante os anos de 1990, al-Liby viveu em Manchester, Reino Unido. Foi indiciado em 2000, pelo grande júri de uma Corte Federal de Nova York, sob a alegação de ter sido um dos mentores dos ataques a bomba em 1998, realizados pela Al Qaeda contra as Embaixadas dos EUA, de Nairóbi, no Quênia, além da missão diplomática norte-americana da Tanzânia, e que resultaram na morte de mais de 220 pessoas, na maioria civis, além de milhares de outros feridos. Al-Liby figurou por mais de uma década na lista dos mais procurados do FBI - Agência Federal de Investigação dos EUA, com uma oferta de recompensa de US\$ 5 milhóes pela sua captura. Segundo o New York Times, al-Liby foi levado para interrogatório a bordo do navio de guerra norte-americano USS Antonio, no Mediterrâneo, mas devido a problemas hepáticos - hepatite C, al-Liby seguiu para os EUA onde foi apresentado à Corte Federal de Nova York para julgamento, sob acusação de terrorismo, onde alegou inocência. Em 02 de janeiro de 2015, al-Liby morreu devido a complicaçóes de câncer hepático, antes que a Corte de Nova York pudesse ter concluído o seu julgamento (AHMED, SMITH \& STEPHEN, 2013; BBC, 2013 e BBC, 2015).

Um dia após a captura de al-Liby, o governo da Líbia negou ter autorizado a operação e disse que Washington tinha questóes para responder sobre o ocorrido. Os serviços de segurança da Líbia negaram qualquer conhecimento prévio sobre a operação, enquanto que o seu Primeiro-Ministro - Ali Zeidan, disse que autoridades dos EUA foram contatadas para fornecerem esclarecimentos e que quaisquer acusaçốes contra um cidadão líbio deveriam ser endereçadas a um tribunal local da Líbia (DW, 2013). Entretanto, um oficial sênior do Exército norte-americano declarou, em anonimato, que o governo líbio havia concedido autorização tácita para a operação, mas que suas autoridades não tiveram qualquer participação nos atos concretos de captura de al-Liby, e que não sabiam o momento exato em que tal iria ocorrer (SCHMIDT \& SCHMITT, 2013).

Cinco dias após a operação norte-americana, e sob pretexto de que o governo líbio sabia de tudo e que, além disso, teria autorizado a entrada das forças especiais dos EUA no território da Líbia, fato não comprovado, seu Primeiro-Ministro, Ali Zeidan, foi sequestrado por uma milícia armada durante a madrugada, enquanto dormia no hotel de luxo, no centro de Trípoli, que funciona como residência e local oficial de trabalho do governo. Por volta das $2 \mathrm{~h}: 30$, do dia 10 de outubro de 2013, cem homens armados arrastaram Ali Zeidan de sua cama, evento que expôs a situação de fragilidade do governo central da Líbia, país onde as milícias armadas possuem grande poder, ao ponto de dificultar a 
produção de petróleo, promover a interrupção do fornecimento de água da capital, cortes forçados de energia, além de participar de contrabando de armas e do tráfico de drogas - tudo impunemente. Poucas horas após o seqüestro, Ali Zeidan foi libertado e, no seu agradecimento público, conclamou os grupos armados, que participaram da sua libertação, a ajudarem na construção do Estado. Em seu discurso na rede de televisão, declarou: "I hope that they would be a part of the state, and have an effective role through its civil and military institutions" (GALL, 2013).

A Líbia é um Estado que, por 42 anos, entre 1969 a 2011, esteve sob o poder absoluto de Muammar al-Gaddafi, conhecido por desrespeito aos direitos humanos e pelo rígido controle sobre a mídia. Durante seu governo, a Líbia assumiu a autoria do atentado que derrubou o vôo da companhia aérea PanAm, ocorrido em 1988 sobre a cidade escocesa de Lockerbie, e que matou 270 pessoas (BBC, 2011). Segundo a atual representante diplomática do governo líbio perante os EUA, Wafa Bugaighis, a Líbia pós-Gaddafi não pode ser comparada aos outros Estados, os quais possuem instituições fortes, exércitos e polícia. Conforme declarou em entrevista na época do fato:

$\mathrm{Na}$ Líbia não tínhamos instituiçôes. Gaddafi era conhecido por proteger a si mesmo e ao povo através de brigadas, e sua principal preocupação sempre foi apenas se livrar de qualquer um que se opunha a ele. Havia laços fortes de segurança, mas nós não tínhamos exército nacional ou polícia nacional. Tudo foi criado para protegê-lo e para mantê-lo no poder o maior tempo possível. Depois da guerra, nós estávamos de frente para uma realidade: nenhuma administração, nenhuma instituição, nenhuma capacidade para fazer funcionar um Estado, e não é fácil fazer funcionar um grande Estado como a Líbia, com fronteiras infinitas e com tremenda paisagem. Não foi apenas uma revoluçáo, mas uma guerra. E isso não foi fácil. E você não espera que um país fique bem da noite para o dia, ou ao longo de um ano, um país que foi devastado e privado de civilidade por 42 anos. (GALL, 2013, tradução nossa).

O Secretário de Estado norte-americano, John Kerry, que estava participando de um Fórum Econômico na Indonésia, insistiu que:

A captura de al-Liby obedece a legislação dos Estados Unidos. O suspeito era um alvo legal e apropriado para as Forças Armadas norte-americanas e deveria ser levado para encarar a justiça em um Tribunal. É importante não simpatizar-se com terroristas procurados. Nós esperamos que isso deixe claro que os Estados Unidos da América jamais irão parar os seus esforços para julgar os responsáveis por atos de terror. Membros da $\mathrm{Al}$ Qaeda e de outras organizaçóes terroristas podem literalmente correr, mas não podem se esconder. (AHMED, SMITH \& STEPHEN, 2013, tradução e grifo nossos). 
Durante o mesmo fim de semana em que al-Liby foi preso, um outro grupo de elite das Forças Armadas norte-americanas, o Seal Team 6, vinculado ao Comando de Operaçóes Especiais da Marinha, responsável pela morte de Osama Bin Laden, também fez incursão em território estrangeiro, desta vez na Somália. A operação tinha por objetivo capturar um líder do grupo Al-Shabaab, uma organização que possui aliança formal com a Al Qaeda. Diferente do caso líbio, o Primeiro Ministro da Somália, Abid Farah Shirdon, afirmou ao jornal The Guardian: "nós congratulamos qualquer operação para caçar os líderes terroristas e nós estamos na vanguarda. Al-Shabaab é um problema da Somália, um problema regional, um problema do mundo". Entretanto, o Dr. Adekeye Adebajo, diretor executivo do Centro para a Resoluçáo de Conflitos da África do Sul, disse que, embora seja do interesse dos governos africanos combater o terrorismo, ele náo considera útil a maneira pesada e unilateral com que os EUA atuam na regiáo, pois corre-se o risco de causar mais instabilidade, especialmente onde há governos fracos, como na Líbia e Somália (AHMED, SMITH \& STEPHEN, 2013, tradução nossa).

Em 18 de outubro de 2013, o Editorial do The Boston Globe chamou a atenção para a mudança de estratégia dos EUA no combate ao terrorismo, com a seguinte afirmação:

Foi uma vitória para a justiça quando Abu Anas al-Libi, um suspeito da Al Qaeda, ter sido apresentado diante de um juiz na terça-feira em um Tribunal Federal de Nova York. [...] A mensagem que o governo dos EUA enviou foi clara: os americanos têm memórias longas. Suspeitos de terrorismo podem correr, mas não podem se esconder. Mas havia uma outra mensagem na apresentação de Libi em Nova York, ao invés de ter sido levado à Baía de Guantánamo. O sistema de justiça americano é justo. Pessoas acusadas de crimes pelo governo dos EUA devem ser julgadas em tribunais norte-americanos, e não deixadas ao limbo indefinidamente. [...] Ao longo dos últimos quatro anos, o sistema judicial federal tem provado ser mais do que capaz de julgar tais casos. Pelo menos 125 pessoas foram condenadas por acusaçôes de terrorismo em Tribunais federais desde 2009. Enquanto isso, julgamentos militares na Baía de Guantánamo ainda não produziram uma única condenação (THE BOSTON GLOBE, 2013, tradução e grifo nossos).

Esta opiniáo mostra o valor que a sociedade norte-americana, ou pelo menos setores da mídia, vem atribuindo à busca de justiça contra terroristas através da intervenção do Poder Judiciário estadunidense. De leste a oeste, as posiçóes editoriais foram semelhantes. O Editorial do Los Angeles Times, na mesma altura, afirmou que:

a captura de Abu Anas al Liby - e uma incursão no mesmo dia na casa de um líder da filial da Al Qaeda na Somália - sugerem que a administração Obama está disposta a incorrer nos riscos necessários para capturar alguns supostos terroristas vivos. Isso pode sinalizar uma mudança tardia 
de uma política controversa e contraproducente de assassinatos seletivos (LOS ANGELES TIMES, 2013).

Por sua vez, o Departamento de Estado norte-americano, através de sua porta-voz Mary Harf, em uma conferência de imprensa oferecida no dia 07 de outubro de 2013, afirmou que de fato o governo dos EUA tem interesse em capturar terroristas vivos, pois o ganho com inteligência através desta via é bastante superior, disse que os EUA não se esquecem dos seus cidadáos mortos em ataques terroristas, ressaltou a capacidade das Forças Armadas norte-americanas de buscarem terroristas em qualquer parte do mundo e que irão continuar a "buscar justiça” permanentemente. Ponderou que al-Liby, após sua captura, foi encaminhado detido para local seguro, fora de Guantánamo e com todos os seus direitos humanos preservados. Sobre a violação da soberania do Estado líbio, disse que não ocorreu porque a Líbia é um país parceiro no combate ao terrorismo, mas sobre a suposta ausência de autorização do Estado líbio, declinou de responder a essa pergunta, pois não iria entrar em "detalhes de assuntos diplomáticos". Quanto ao fato da captura ter ocorrido sob amparo da Lei de Autorização do Uso da Força Militar (AUMF), uma Resoluçáo Conjunta do Congresso dos Estados Unidos da América de 2001, notadamente se essa lei seria aplicável fora do território norte-americano e a cidadãos estrangeiros, a porta-voz limitou-se a dizer que este é um "assunto para advogados" (HARF, 2013).

O Departamento de Defesa dos EUA, em comunicado emitido pelo Secretário de Imprensa do Pentágono, George Little, apresentou posição clara sobre o fato: a captura de al-Liby foi legal sob amparo do Direito de Guerra, pois ele era membro da organização terrorista Al Qaeda, com a qual os Estados Unidos da América encontram-se atualmente em conflito armado. O Pentágono ponderou que al-Liby foi detido e levado legalmente para local seguro fora da Líbia, que a prioridade é e sempre foi prender terroristas vivos, para obter informaçôes de inteligência sobre outras operaçôes da Al Qaeda e para ajudar a proteger o povo dos Estados Unidos da América. Disse que al-Liby já havia sido indiciado por um Tribunal Federal em Nova York, por participaçáo nos ataques terroristas da Al Qaeda, que mataram civis norte-americanos no Quênia e na Tanzânia, e que al-Liby estava envolvido em planos para novos ataques contra interesses e instalaçóes dos EUA localizados na Arábia Saudita, no Yemen e na Somália. O sucesso da operaçáo, que não causou quaisquer danos materiais, nem mortos nem feridos, foi atribuído à coordenação entre os serviços de inteligência norte-americanos e as agências de segurança nacional, e que em todas as suas fases contou com a autorizaçấo do Presidente Barack Obama (LITTLE, 2013).

Em seu pronunciamento à imprensa, ocorrido na Casa Branca, em 08 de outubro de 2013, o Presidente dos Estados Unidos da América, Sr. Barack Obama, foi questionado se as constantes operaçôes contra o terrorismo na África não estão em contrariedade com os seus últimos discursos, em que afirmou que os americanos não podem permanecer 
eternamente em guerra. Obama respondeu que há uma diferença entre estar eternamente em guerra e buscar terroristas que estão causando danos diretos aos EUA. Explicou que na África há o problema da falta de capacidade ou de vontade dos governos locais em combater o terrorismo e que, por isso, os EUA terão que continuar a caçar terroristas naquele continente. Disse que possui planos de longo prazo para região, e que não estão baseados apenas na abordagem militar. A guerra é ideológica e os EUA pretendem atuar ao lado de países muçulmanos para isolar indivíduos radicais específicos, que estão causando mais danos ao próprio Islam do que ao restante do mundo. Mostrou a necessidade de levar desenvolvimento econômico para a região, pois uma massa de jovens desempregados e sem qualificação representam presas fáceis para os recrutadores terroristas. Sobre a legalidade da captura, sob o âmbito do Direito Internacional, Obama declinou de responder e afirmou que os EUA tinham fortes evidências da participação de al-Liby no planejamento e na execução dos atentados que mataram civis norte-americanos em 1998, e que "ele será trazido para a justiça”" (OBAMA, 2013).

A partir do exame das principais notícias que foram publicadas na imprensa, além do que foi divulgado nos editoriais de veículos jornalísticos, e ainda as manifestaçóes oficiais prestadas pelas autoridades dos EUA e da Líbia, o que se percebe é que o motivo determinante para a operação de captura de al-Liby foi a busca por justiça. Embora, para o Estado norte-americano, não haja qualquer dúvida quanto ao aspecto da legalidade dos atos praticados por seu Exército, a ênfase de suas declaraçóes repousa no aspecto axiológico da justiça, no desejo de fazer justiça em favor dos norte-americanos mortos em atentados terroristas. No tópico seguinte, seráo examinados as questóes jurídicas relacionadas diretamente à entrada dos EUA na Líbia, à captura de um cidadão líbio em seu território e o seu posterior envio para julgamento por uma Corte Federal de Nova York. Percebe-se que no plano estrito da legalidade, embora as leis e as convençóes sirvam para trazer mais certeza a qualquer tema, há muitas divergências sobre a juridicidade da ação norte-americana na Líbia.

É importante destacar que, no plano da evolução do Direito Internacional, as mudanças normativas não acontecem em um vácuo jurídico, mas a partir da interação entre regras fundamentais, princípios e processos de criaçáo jurígena. $\mathrm{O}$ poder (habilidade de influenciar comportamentos) tem um papel central neste processo de formação das regras internacionais. Mesmo que o poder seja originário de várias fontes diferentes como, por exemplo, a força militar, a riqueza financeira ou a autoridade moral de um país (habilidade de apelar para princípios gerais de justiça), e mesmo que a diferente natureza destes tipos de poder conduza a diferentes percepçóes da sociedade sobre a qualidade dos seus usos, por exemplo, o chamado poder duro das incursóes militares diretas e das coerçóes econômicas, ou o poder macio da diplomacia e do discurso dos direitos humanos, quase todos igualmente importantes na arena das relaçóes internacionais; o fato é que os Estados 
costumam perseguir os seus próprios interesses de maneiras muito diversas e, aos olhos da sociedade internacional, o que permanece de mais visível não é a legitimidade ou a coercitividade das regras do Direito Internacional (qualidade que uma norma jurídica tem de impor condutas, de criar expectativas de comportamento futuro e de tornar isso aceito pelos seus destinatários). O que sobressai é o poder militar, a pujança econômica e, até mesmo, a autoridade moral dos países que atuam em determinada direçáo, dentro da arena das relaçóes internacionais. Neste cenário, o sistema jurídico formado pelo Direito Internacional nada mais é do que uma estrutura desejada pelos Estados para conferir maior eficiência às suas atuaçóes, além de estabilidade contra o efeito desestabilizador do uso da força. E, sobretudo, os Estados desejam essa estrutura por causa da função, essencialmente social, que o sistema normativo internacional exerce ao transformar a aplicação dura dos vários tipos de poder em obrigaçóes de natureza jurídica. Em outras palavras, transforma aquilo que "é" - poder da supremacia bélica, econômica e moral, naquilo que deve "deve ser" - obrigação de submeter-se. Dentro dessa dinâmica de fatores, uma prática estatal que já vem sendo aplicada por determinado Estado, independente de estar perfeitamente autorizada nos textos das convençóes, tende a transformar-se em costume internacional, vinculante e coercitivo para os demais Estados (BYERS, 2001, p. 3-6).

\section{0 Quadro Jurídico-Normativo}

O primeiro documento que pode ajudar na compreensão do caso é a Carta das Naçóes Unidas, de 1945 , cujo art. $2^{\circ}$, item 4, define como regra geral o dever de todos os Estados membros da ONU de "evitar em suas relaçóes internacionais a ameaça ou o uso da força contra a integridade territorial ou a dependência política de qualquer Estado", mas como exceção é reconhecido o direito de auto-defesa, nos termos do art. 51 abaixo transcrito:

Nada na presente Carta prejudicará o direito inerente de legítima defesa individual ou coletiva no caso de ocorrer um ataque armado contra um Membro das Naçôes Unidas, até que o Conselho de Segurança tenha tomado as medidas necessárias para a manutenção da paz e da segurança internacionais. (ONU, 1945)

A captura de al-Liby foi considerada, pelo Estado líbio, uma violação de sua soberania territorial pois o governo local não autorizou a operação norte-americana, muito embora os EUA afirmem que havia obtido autorização "tácita" da Líbia e que apenas a data da operação não fora informada às autoridades líbias. Apesar das contradiçóes, o governo líbio afirmou que o fato não abalou as relações diplomáticas entre os dois países (SCHMIDT \& SCHMITT, 2013). Neste ponto, é preciso distinguir o consentimento do Estado, que sofre a incursão militar em seu território, e o exercício do direito de 
auto-defesa, por parte do Estado que entra em território estrangeiro, pois, neste último caso, é dispensada a necessidade do consentimento. Outra questáo é que o ataque sofrido pelos EUA foi executado por grupos terroristas privados, não houve agressão estatal da Líbia aos EUA nos atentados de 1998.

Sobre este aspecto, a Corte Internacional de Justiça possui precedente, a partir do caso Congo x Uganda, onde decidiu que não é autorizado o exercício de auto-defesa quando não há uma agressão por organismo estatal, ou seja, não é permitido o direito de auto-defesa contra civis (CIJ, 2005, $\$ \$ 146-47)$. Porém, o texto do art. 51 da Carta da ONU não estabelece qualquer requisito específico sobre a natureza do ataque sofrido por um Estado. Sobre esta questão, é interessante notar o conteúdo da opinião separada do juiz Simma, no mesmo caso acima citado, onde ele chama atenção para os diferentes critérios de decisão adotados por dois órgãos diferentes da ONU: o Conselho de Segurança e a Corte Internacional de Justiça.

Para o Conselho de Segurança, a invasão militar de parte do território do Congo, do tamanho da Alemanha, pelas Forças Armadas estatais de Uganda, constituiu um ato de agressão ilegal que não caracteriza o direito de auto-defesa. Na visão do juiz Simma, o Conselho de Segurança tinha motivos "políticos" para assim decidir. Entretanto, o mesmo juiz sustenta que a Corte Internacional de Justiça não deve seguir esse caminho. Apesar de tudo, a Corte decidiu no mesmo sentido, mas por razóes de ordem técnico-processual, pois Uganda náo conseguiu provar que sofrera agressóes das Forças Armadas estatais do Congo, assim entendeu-se que foram grupos rebeldes, instalados a partir do território congolês, que agrediram Uganda. Neste sentido, considerando que a única prova contida nos autos apontava para uma inequívoca invasão prolongada do território do Congo, perpetrada por Uganda, esse fato foi julgado ilegal. Mas, do ponto de vista de uma hermenêutica mais extensiva, no sentido de ampliar o alcance da norma do art. 51 da Carta da ONU, o juiz Simma, apoiado em entendimento do juiz Kooijmans, conclamou para a necessidade da Corte Internacional de Justiça rever sua jurisprudência interna, para que perceba a mudança que ocorreu na prática internacional e na opinio juris consuetudinária, a partir dos ataques terroristas de 11 de setembro de 2001. Segundo o juiz Simma, a comunidade internacional reconheceu favoravelmente a possibilidade de auto-defesa, em favor dos Estados, contra ataques perpetrados por grupos terroristas privados, cuja natureza é a de atores náo estatais, e esse novo entendimento representou uma mudança de prática consuetudinária muito mais ampla do que qualquer outra releitura já feita em outros dispositivos da Carta da ONU (CIJ, 2005a, $\$ \$ 1-3,12-13)$.

Em um informe distribuído à imprensa pela Casa Branca, em 23 de maio de 2013, cinco meses antes da captura de al-Liby, o governo dos EUA havia publicado a sua linha básica de ação contra o terrorismo, onde informava os seus critérios de uso letal da força contra alvos não militares. Segundo o documento, a mais importante consideração, capaz 
de justificar sua aplicação, é se o uso da força protege vidas da população norte-americana, pois em primeiro lugar, a captura de suspeitos de terrorismo vivos é preferível, dado o ganho de informaçóes de inteligência por esta via. A força letal, quando usada, deve considerar cinco pontos: 1) certeza de que o alvo terrorista está no local; 2) certeza de que os não-combatentes nas proximidades náo serão mortos nem feridos; 3) avaliaçáo de que a captura não é viável; 4) avaliação de que nenhuma outra alternativa é viável para tratar da ameaça às pessoas dos EUA; 5) finalmente, quando o uso da força ocorrer em territórios estrangeiros, os princípios jurídicos do Direito Internacional, incluindo o respeito pela soberania e pelo Direito dos Conflitos Armados, impóem restriçóes importantes à capacidade dos EUA de agirem de modo unilateral, e no modo pelo qual podem usar a força. Neste ponto, os EUA declaram o seu respeito pela soberania nacional e pelo Direito Internacional (WHITE HOUSE, 2013).

Desde 18 de setembro de 2001, em razão da "violência traiçoeira" perpetrada contra os Estados Unidos da América e os seus cidadãos, a Resolução conjunta do Congresso Nacional, de n. 23, Public Law 107-40 (AUMF), autoriza o Presidente a usar poderes de guerra:

AUTORIZAÇÃO PARA USO DAS FORÇAS ARMADAS dos Estados Unidos.

(a) EM GERAL - Que o Presidente está autorizado a usar toda a força necessária e apropriada contra as naçóes, organizaçóes, ou pessoas que ele determine ter planejado, autorizado, cometido ou ajudado nos ataques terroristas ocorridos em 11 de setembro de 2001, ou abrigavam tais organizaçóes ou pessoas, a fim de evitar quaisquer atos futuros de terrorismo internacional contra os Estados Unidos por tais naçóes, organizaçóes ou pessoas.

(b) PODERES DE GUERRA - REQUISITOS

(1) AUTORIZAÇÃO ESPECÍFICA - Consistente com a seção 8(a)(1) da Resolução de Poderes de Guerra, o Congresso declara que esta seção é destinada para constituir autorização estatutária específica, na acepção do ponto 5(b) da Resolução de Poderes de Guerra (US CONGRESS, 2001, tradução nossa).

Segundo um estudo publicado pelo Jornal de Segurança Nacional, da Universidade de Harvard, a AUMF foi assinada pelo Congresso para autorizar o combate a alvos específicos que, na altura, eram as "nações, organizaçóes ou pessoas" ligadas à Al Qaeda e ao Talibã. Entretanto, mais de uma década depois essa lei nunca foi emendada, e as ameaças daquele tempo estão hoje todas dizimadas, já que o Talibã foi removido do poder no Afeganistão, Osama Bin Laden foi assassinado e os lideres remanescentes da $\mathrm{Al}$ Qaeda estão sob custódia norte-americana. Porém, isso não significa que os EUA eliminaram a ameaça terrorista em si. Recentemente, em janeiro de 2013, um ataque terrorista levou ao 
sequestro e à morte de 37 reféns em uma refinaria de gás na Argélia, situada a $50 \mathrm{~km}$ da fronteira com a Líbia. Em abril do mesmo ano, o atentado ocorrido na maratona de Boston, perpetrado individualmente por dois irmãos chechenos, matou 3 pessoas e feriu 264 outras. Estes fatos, segundo o estudo, mostram um profundo e raro consenso, na política e no direito: o combate autorizado pela AUMF não é mais contra as mesmas pessoas que perpetraram o ataque do 11 de setembro e, por isso, a lei precisa ser alterada para permitir medidas progressivas de defesa e segurança por parte do Presidente, contra novas ameaças terroristas, mas isso exige o cumprimento de um rigoroso processo administrativo capaz de, com segurança, identificar grupos ou pessoas particularmente relacionadas aos atos de terrorismo. $\mathrm{O}$ estudo propóe mais transparência ao processo de identificaçáo de terroristas; o encerramento definitivo da frente de combate e retirada das tropas militares do Afeganistão, para evitar a principal crítica dos últimos anos, de uma "guerra eterna" e, em terceiro lugar, revogar e substituir a AUMF por uma lei que autorize especificamente o combate contra a Al Qaeda da península arábica (DASKAL \& VLADECK, 2014, p. 116-117).

A questão é complexa e não permite que se façam considerações estritamente jurídicas, sob o âmbito exclusivamente formal das leis ou das convençóes existentes, sem que se olhe para a realidade dos fatos. O caso líbio de 2013 ocorreu, conforme já mencionado no primeiro tópico deste paper, em um contexto de completo caos que a Líbia enfrentava, uma situação fática decorrente do conflito interno de poder entre milícias armadas que, até hoje, lutam para ocupar o vácuo de governo deixado após a queda do regime de Gaddafi. O Direito Internacional e todas as suas convençóes, durante o longo processo em que são propostas, discutidas e elaboradas as normas que irão regular os direitos, as obrigaçóes e as proibições entre Estados, tudo isso pressupóe uma negociação realizada entre países que estejam em condições, minimamente, de funcionar uma organização estatal doméstica e colocar em execução os dispositivos do direito estabelecido. Não era essa, todavia, a situação da Líbia na data em que a captura de al-Liby aconteceu.

A este respeito, é válido notar uma das conclusôes que foram publicadas pelo Caderno de Estudos em Direito Internacional, veículo de pesquisa do Colégio de Guerra Naval da Marinha dos EUA. Segundo referido estudo, cujo conteúdo é de responsabilidade dos autores do texto, membros das Marinhas de Guerra britânica e norte-americana, e que não representam as posiçóes oficiais dos respectivos governos, conforme pondera o Colégio, para que um Estado use a sua força militar em território estrangeiro, sem que isto viole soberania estatal alheia, é preciso primeiro compreender que o conceito de soberania envolve uma dupla dimensão. Se por um lado significa o direito de autodeterminação interna de um Estado, por outro lado representa o dever e a obrigação de não permitir que, a partir do seu território, atos de terrorismo sejam planejados, articulados e executados ao ponto de ameaçar vidas em outros territórios. Este equilíbrio de interesses pressupóe 
que seja dada uma oportunidade, antes do Estado sofrer incursão de Forças Armadas estrangeiras, a chance de ele próprio suprimir as ameaças terroristas que estejam partindo de dentro do seu território. Apenas no caso desse Estado falhar, ou no caso de não ter vontade de fazê-lo, é que a incursão militar estrangeira será legítima e não violadora da sua soberania nacional. Em tais casos, o Estado que vem a ser vítima de um ataque terrorista possui o direito de auto-defesa, isto é, o direito de entrar em território alheio até mesmo sem aviso prévio (MODARAI et al., 2013, p. 822).

Um segundo documento que merece ser examinado, para melhor compreensão do caso al-Liby, é a Quarta Convenção de Genebra relativa à Proteção das Pessoas Civis em Tempo de Guerra, de 12 de agosto de 1949. O âmbito de aplicação desta convenção, conforme seu artigo $2^{\circ}$, abrange todos os casos de guerra declarada ou qualquer outro conflito armado, entre dois ou mais Estados, mesmo que a situação de guerra não seja reconhecida por uma das partes envolvidas no conflito. Referida convenção proíbe a tomada de reféns, a transferência individual ou coletiva de civis para fora do território onde ocorre o conflito e determina que as pessoas, acusadas da prática de ofensas, devem ser detidas e julgadas no seu próprio território e, caso condenadas, neste mesmo país devem cumprir suas penas (ONU, 1949, artigos 34, 49 e 76). Por outro lado, parece haver virtual conflito de normas em relação ao Protocolo I, relativo à Proteção de Vítimas de Conflitos Armados Internacionais, documento adicional às Convençóes de Genebra de 1949, elaborado em 8 de junho de 1977. O âmbito de aplicação desta convenção é idêntico ao da Quarta Convenção examinada acima, pois seus artigos $2^{\circ}$ são comuns, porém, nos termos da Convençáo de 1977, é permitido ataque militar contra alvo (objeto) civil sempre que este represente uma ameaça. Para os efeitos desta convenção, consideram-se civis quaisquer pessoas que não pertençam à categoria dos combatentes, conjunto de indivíduos que são definidos como os membros de forças armadas regulares, de grupos e unidades organizados, sob o comando de um dos Estados que participam do conflito, mesmo que seu governo ou autoridade não sejam reconhecidos pelo adversário (ONU, 1977, artigos 43, 50[1] e 52[1] e [2]).

Embora a regra geral, contida no artigo 51[2] desta Convenção de 1977, seja a proibição de ataques à população (pessoas) civil, o fato é que existe uma exceção no artigo $52[2]$, capaz de gerar interpretação duvidosa. Isto acontece porque, nos casos em que um "objeto" civil, por exemplo, templos, casas e escolas, esteja sendo utilizado diretamente para hostilidades, nestas situaçóes uma Força Militar estrangeira pode lançar ataques a estes objetos para fins estritamente necessários à cessação da ameaça, e com uso dos meios e da força proporcionais e adequados à finalidade de neutralizar referido local, podendo haver destruição total ou parcial, além de captura (ONU, 1977). A dúvida ocorre justamente em relação ao vocábulo "captura", pois embora o contexto considerado pela convenção seja o de "lugar", isto é, instalaçóes civis que venham a ser usadas em um combate, fora dos seus usos civis normais; não existe na norma uma delimitação específica sobre o 
alcance do vocábulo "captura”. Tanto pode referir-se à captura de uma escola, de um templo, como também a captura de uma pessoa civil, muito embora não exista autorização explícita para "ataque" militar contra pessoas civis.

Portanto, no que refere à legalidade da captura de al-Liby em território líbio, esta ainda é uma questão polêmica e sujeita a muitas interpretaçóes. Em 2010, porém, surgiu um entendimento sobre a possibilidade de se fazer algo muito mais grave do que a mera captura de um civil: o seu "assassinato seletivo". Este tema envolve dois problemas: a natureza dos participantes de um conflito armado e a possibilidade de intervenção militar contra civis, executada por Forças Armadas regulares. Em relação ao primeiro ponto, um estudo realizado pelo Conselho de Direitos Humanos da ONU chegou à conclusão de que, independente do conflito ocorrer entre Estados (conflito armado internacional) ou entre um Estado e grupo armado não estatal (conflito armado não internacional), como é o caso do combate ao terrorismo, os padróes jurídicos do Direito Humanitário Internacional aplicam-se de modo idêntico. Quanto ao segundo ponto, o mesmo estudo aponta que, se for comprovado que um civil está diretamente associado aos combates e às hostilidades contra uma nação estrangeira, as Forças Armadas regulares deste Estado podem, em nome do direito de auto-defesa, executar o chamado "assassinato seletivo". Como requisitos de legalidade desta medida, o assassinato deve ser militarmente necessário e limitado por critérios de proporcionalidade da força que venha a ser utilizada, de modo a evitar o cometimento de erros e a produçáo de danos para outros civis náo envolvidos no combate. E, quanto à soberania do Estado, em cujo território ocorra um "assassinato seletivo" de civil, não ocorre sua violação sempre que o Estado que executa a incursão tiver recebido consentimento do Estado que sofre a incursão ou, na ausência de consentimento, este Estado não tiver demonstrado vontade ou capacidade de neutralizar as ameaças originárias de dentro do seu território (ONU, 2010, p.10-12).

Um quarto documento importante para esta questão é a Convenção Internacional sobre a Supressão de Atentados Terroristas com Bombas, adotada em 15 de dezembro de 1997. Interessante notar que este documento recebeu adesão da Líbia, através de acessão em 22 de setembro de 2000, e ratificaçáo dos EUA em 26 de junho de 2002. Portanto, os dois Estados já tinham aderido à mesma norma de Direito Internacional quando o cidadão al-Liby foi capturado em território líbio. Nas consideraçóes introdutórias deste documento, é reconhecido que as atividades das forças militares dos Estados são regidas por normas do Direito Internacional, fora do contexto desta Convenção, e que a exclusão de certos atos do âmbito desta Convenção não justifica, nem tampouco legitima, atos ilícitos de qualquer natureza, nem prejudica seu processo ao abrigo de outras leis (ONU, 1997, preâmbulo). Isto denota que as Partes Contratantes demonstraram interesse em submeter atividades militares, realizadas em território estrangeiro, ao âmbito da regulação jurídica doméstica, pois tratados e convençôes internacionais são significam a mesma coisa que 
leis. Este tipo de abordagem da questão, onde convenções internacionais são elaboradas com o objetivo de serem aplicadas em conjunto com a regulação doméstica, parece uma tentativa de ampliar o universo de normas passíveis de serem utilizadas como base jurídica do combate ao terrorismo.

Chama a atenção o artigo 60[5] desta Convenção de 1997, segundo o qual suas normas não excluem o exercício da jurisdição penal estabelecida por um Estado Parte, de acordo com sua legislação interna. Ao mesmo tempo, o artigo $8^{\circ}$ dispóe que, nos casos em que se aplique o artigo $6^{\circ}$, e caso o Estado Parte, em cujo território se encontrar um suspeito de terrorismo, não proceda a sua extradição, deverá submeter o caso sem demora às suas autoridades internas com vistas à abertura de processo. $\mathrm{O}$ artigo 17 coloca princípios de respeito à igualdade soberana, à integridade territorial dos Estados e da não-intervenção em seus assuntos internos. $\mathrm{O}$ artigo 18, de modo expresso, proíbe que um Estado exerça sua jurisdição no território de outro Estado, ou nele realize funçóes exclusivamente reservadas às autoridades desse outro Estado por seu direito interno, entretanto o artigo 19[2] dispóe que:

As atividades das forças armadas durante um conflito armado, conforme definidas pelo direito internacional humanitário e por este regidas, não estarão sujeitas à presente Convenção e tampouco o estarão as atividades realizadas pelas forças militares de um Estado no cumprimento de suas funçôes oficiais, sempre que forem regidas por outras normas do direito internacional. (ONU, 1997, grifos nossos)

Da leitura das normas acima, parece que esta Convenção legitima de modo exato os atos que os EUA praticaram em território líbio: utilização das Forças Armadas para, em nome e no interesse da persecução criminal de sua jurisdição doméstica, capturar um cidadão que já estava indiciado por terrorismo em uma Corte Federal de Nova York, desde 2000.

Entretanto essa não é a opinião da Suprema Corte do Reino Unido que, em caso análogo, ocorrido em fevereiro de 2004, considerou ilegal prima facie a captura de um cidadão paquistanês no Iraque, pelas Forças Armadas britânicas, e sua posterior detenção fora do país, em uma Base Aérea localizada no Afeganistão, onde permaneceu sob custódia das Forças Armadas dos EUA, sob pretexto de que o prisioneiro estaria envolvido com o grupo terrorista Al Qaeda. O caso teve início quando as Forças Armadas dos EUA, do Reino Unido e da Austrália assinaram um "Memorando de Entendimento", em 23 de março de 2003, sem força coercitiva, mas apenas com valor diplomático entre os três países envolvidos. Segundo o documento, a remoção de prisioneiros de guerra para fora do Iraque só poderia ser feita mediante acordo entre os EUA e o Reino Unido, conforme as regras da Quarta Convenção de Genebra relativa à Proteção das Pessoas Civis em Tempo de Guerra, de 1949. Porém, o Reino Unido alegou que o prisioneiro foi retirado 
do Iraque pelos EUA sem seu conhecimento. O cidadáo em tela, Sr. Yunus Rahmatullah, tentou obter uma ordem de livramento através de um habeas corpus que, em primeira instância, foi negado. A Corte de Apelaçóes, por sua vez, aceitou o pedido e determinou ao Secretário de Estado para Assuntos Estrangeiros e ao Secretário de Estado da Defesa do Reino Unido que buscassem junto às autoridades dos EUA a devoluçáo do Sr. Rahmatullah para a custódia britânica, a fim de que o mesmo fosse libertado. Em cumprimento da ordem, as autoridades britânicas escreveram ao governo dos EUA, mas este respondeu no sentido de que iria tratar do caso diretamente com o governo do Paquistão, país de nascimento do prisioneiro. Por conta dessa resposta, a Corte de Apelaçôes encerrou o caso, entendendo que os réus cumpriram a ordem dentro do que lhes foi possível. Todavia, o caso foi submetido à Suprema Corte do Reino Unido, cuja decisáo foi no sentido de que, embora o Memorando de Entendimento de 2003 não fosse coercitivo, as autoridades britânicas e norte-americanos possuíam obrigaçōes no âmbito da Convenção de Genebra de 1949. Embora a legalidade da prisão do Sr. Rahmatullah não tivesse sido o objeto central do seu pedido de habeas corpus, a Suprema Corte entendeu que havia evidência prima facie de que sua detenção era ilegal no âmbito da Convenção de Genebra de 1949. E, além disso, o Reino Unido tinha a obrigação de garantir que o Sr. Rahmatullah não permanecesse preso em violação às regras da Convenção de Genebra de 1949. O ponto central do julgamento foi que as autoridades do Reino Unido, por terem sido as primeiras que, inicialmente, prenderam o Sr. Rahmatullah, mantiveram a responsabilidade continuada pela sua detençấo, sob a ótica da Convenção de Genebra e, por isso, tinham o direito absoluto de exigir sua entrega pelos EUA, independente do Memorando de Entendimento entre os três países (UKSC, 2012).

Em sentido oposto, a Suprema Corte dos EUA decidiu, em 29 de junho de 2004, que a captura de um cidadão mexicano no México, e sua posterior detenção em território estadunidense, por agentes norte-americanos da DEA - Agência de Combate às Drogas, não viola as normas consuetudinárias internacionais, nem o Tratado de Extradição entre os EUA e o México, e nem viola a competência da Corte Federal que autorizou essa prisão. O caso teve seu início em 1985, quando o agente da DEA, Enrique Camarena Salazar, foi capturado durante uma missão no México e levado para a cidade de Guadalajara, onde foi torturado por 2 dias e, depois, morto. Baseados em prova testemunhal, oficiais da DEA acreditaram que o cidadáo mexicano Humberto Alvarez-Machain, um médico, esteve presente durante toda a tortura, para prolongar a vida de Camarena. Em 1990, um grande júri federal indiciou Alvarez por tortura e assassinato, e o Distrito Central da Califórnia emitiu uma ordem de prisão contra ele. Os oficiais da DEA pediram auxílio ao governo do México para levar Alvarez aos EUA. Mas quando perceberam que seria inútil esse pedido, planejaram uma operação de captura e sequestraram Alvarez na sua casa, mantiveram-no por uma noite em um motel e, no dia seguinte, levaram-no para a cidade de 
El Paso, no Texas, onde foi preso por oficiais federais. Uma vez sob custódia norte-americana, Alvarez moveu ação judicial alegando que sua prisão foi uma "ultrajante conduta governamental" dos EUA e que violara o Tratado de Extradição entre esse país e o México. Em 1992, a Corte Distrital aceitou estes argumentos e o Nono Circuito confirmou-os. Em 1993, já no México, Alvarez propôs nova ação judicial em busca de indenizaçáo contra os EUA, com base em prisão arbitrária por falsos motivos e violação do Direito Internacional Consuetudinário. A Corte Distrital e o Nono Circuito confirmaram o direito de Alvarez receber US\$ 25 mil de indenização. O caso chegou à Suprema Corte dos EUA, sob alegação do governo estadunidense de que a prisão não teria sido arbitrária, porque fora autorizada por uma Corte Federal norte-americana e que a responsabilidade pretendida contra os EUA entra no campo das imunidades soberanas contra reivindicaçóes apresentadas a partir de país estrangeiro. Em sua decisão, a Suprema Corte dos EUA disse que Alvarez não conseguiu provar o suposto costume internacional e que, a aceitação de seus argumentos criaria uma nova causa de ação judicial contra qualquer prisão de estrangeiros, o que viola a Quarta Emenda. Além disso, a Lei de Relaçóes Exteriores dos EUA proíbe apenas prisões arbitrárias "prolongadas”, e não detençôes breves com excessos de autoridade. Receber açóes judiciais contra os EUA, motivadas por violação do Direito Internacional, exige das Cortes Federais um especial cuidado para não criar novos critérios colidentes com os padróes utilizados pelo Legislativo e pelo Executivo nos assuntos externos. Por fim, o Judiciário náo possui mandato do Congresso que incentive uma maior criatividade judicial capaz de definir novos e discutíveis padróes de violação do Direito Internacional (SCUS, 2004).

O que se percebe das normas internacionais examinadas até aqui é que as convençóes e os tratados, quando não são divergentes nos seus vocábulos internos, fato por si só gerador de múltiplas e possíveis interpretaçóes quanto ao seu sentido, referidas convençóes possuem um acentuado modelo de legislação baseado em regras e exceçóes. A maioria das convençôes aplicáveis ao caso da captura de al-Liby estabelecem, como regra, a proibição do uso da força contra o território de determinado Estado mas, excepcionalmente, pode-se utilizar o direito de auto-defesa. Outro aspecto observado é a exceção, específica, quanto ao uso das Forças Armadas e o exercício de poderes estatais, no caso do artigo 18 da Convenção Internacional sobre a Supressão de Atentados Terroristas com Bombas (ONU, 1997). Como visto acima, essa convenção traz, de regra, a proibição do exercício da jurisdição em território alheio, além da proibição do exercício de funçóes estatais exclusivas das autoridades internas de um dado país. Mas, excepcionalmente, o artigo 19[2] dispóe que as atividades das Forças Armadas ficam fora do âmbito desta convenção.

Se compararmos os dois casos analisados, perceberemos que o princípio da especialidade afasta a aplicação da Convenção sobre a Supressão de Atentados Terroristas, de 1997, quanto aos casos de combate ao tráfico de drogas. Neste sentido, embora o caso da 
captura do cidadáo mexicano tenha sido um claro exemplo de atividade policial dos EUA em território mexicano, no cumprimento de uma ordem jurisdicional, ou seja, conduta claramente vedada por esta convenção, e, além disso, se consideramos que o fato ocorreu em 1985, antes, portanto, da referida norma ter sido produzida, teremos como resultado uma conduta norte-americana que, segundo sua Suprema Corte de Justiça, não teria violado o Direito Internacional. Porém, para o caso de al-Liby, as posiçóes jurisprudenciais não são divergentes, apesar das divergências que, como notado, existem em grande quantidade nos próprios textos das convençôes internacionais. A Suprema Corte do Reino Unido considerou, em caso análogo, que havia prima facie uma violação das Convençôes de Genebra de 1949, no que tange à captura de civil por Forças Armadas estrangeiras (UKSC, 2012). Por sua vez, a Corte Internacional de Justiça entendeu que não é permitido o direito de auto-defesa contra civis (CIJ, 2005, \$\$ 146-47). Mas no âmbito político, como, por exemplo, o Conselho de Direitos Humanos da ONU, o entendimento é diametralmente oposto, pois referido órgáo possui um estudo jurídico que defende com toda clareza a possibilidade de incursóes militares em território estrangeiro até mesmo para praticar "assassinato seletivo" contra civis que sejam considerados uma ameaça, em eventual conflito armado envolvendo Estados (ONU, 2010, p.10-12).

Uma primeira conclusão à qual se pode chegar é que os órgãos políticos da $\mathrm{ONU}$ possuem um posicionamento oposto ao que os órgáos jurisdicionais da própria ONU defendem. Inclusive a Justiça do Reino Unido também possui entendimento divergente sobre a legalidade da captura de civis por Forças Armadas estrangeiras. Alguns juízes da Corte Internacional de Justiça, de modo isolado, tem defendido a necessidade desta Corte de atualizar sua jurisprudência interna para acompanhar a mudança que ocorreu na prática internacional após os atentados de 11 de setembro. Embora o exemplo utilizado pelo juiz Simma (CIJ, 2005a, $\$ \$ 1-3,12-13$ ), para embasar sua opiniáo separada, tenha sido o caso da invasáo das Forças Armadas de Uganda contra o território do Congo, em resposta a uma agressão, não comprovada, originária de grupos rebeldes privados, fato que foi considerado ilegal pelo Conselho de Segurança da ONU; este mesmo Conselho vem agora reconhecer o direito de auto-defesa contra os atentados terroristas do 11 de setembro. Tudo isso permite concluir que o "direito" a ser aplicado em determinada questáo de alcance internacional, notadamente o combate ao terrorismo, pode muitas vezes estar além do que os textos dos tratados e das convençôes estabelecem, pois parece, de modo bastante claro, que o motivo das decisóes políticas da ONU, e das decisōes jurídicas da sua Corte Internacional de Justiça, ao menos na visão do juiz Simma, repousa ou deveria repousar na prática internacional, conjunto de açóes e omissóes dos Estados que levam à formação de uma opinio juris, tecnicamente denominada costume internacional.

Para confirmar esta observação, basta examinar o teor das Resoluçôes do Conselho de Segurança da ONU, n. 1368, 1373 e 1377, de 2001, elaboradas todas elas um dia, ou 
semanas, após os atentados terroristas do 11 de setembro, em cujos textos é perfeitamente possível identificar uma ênfase pela busca de justiça. Embora haja ressalvas à necessidade de respeito à Carta das Naçóes Unidas, ao Direito Internacional como um todo e aos direitos humanos, essa ênfase pela busca de justiça autoriza a auto-defesa através de todos os meios, o que em outras palavras, poderia ser traduzido como exemplo de resposta militar internacional contra uma ameaça que, devido à sua enorme magnitude, justifica os meios.

A Resolução n. 1368, de 12 de setembro de 2001, em um momento onde já se sabia que os ataques não tinham sido perpetrados por Estado estrangeiro, mas por grupos terroristas privados, reconheceu o direito inerente de auto-defesa individual ou coletiva de acordo com a Carta das Naçóes Unidas, determinou o combate por todos os meios contra as ameaças à paz e à segurança internacionais, conclamou todos os Estados para trabalharem juntos e para trazerem à justiça os financiadores, os organizadores e os perpetradores dos ataques terroristas (ONU, 2001). Por sua vez, a Resolução 1373, de 28 de setembo de 2001, reafirmando os termos da resolução anterior, decidiu que os Estados membros deverão negar refúgio para pessoas que financiam, planejam apóiam ou cometem atos terroristas e impedir que seus territórios sejam usados por tais pessoas para a prática de atos terroristas contra outros Estados; que os Estados deverão prestar apoio mútuo no processo de investigaçóes ou procedimentos criminais relacionados ao terrorismo; convoca todos os Estados a cooperar administrativa e judicialmente para impedir a execução de atos terroristas (ONU, 2001a, artigo 2[c], [d] e [f]; artigo 30[b]). Finalmente, a Resolução 1377, de 12 de novembro de 2001, reafirma as resoluçóes anteriores e declara que o terrorismo é uma das mais sérias ameaças à paz e à segurança internacional no século XXI, sublinha que o terrorismo póe em perigo vidas inocentes e a dignidade humana, ameaça o desenvolvimento social e econômico de todos os Estados e enfraquece a estabilidade e a prosperidade global; conclama todos os Estados a prestarem assistência mútua na implementação da Resolução 1373 (ONU, 2001b). Em complemento às resoluçóes da ONU relativas ao combate ao terrorismo, o Conselho de Segurança já havia autorizado a elaboração de uma lista de indivíduos e entidades ligados à $\mathrm{Al}$ Qaeda, lista em cujo texto o nome de Anas Al-Liby, que já tinha sido indiciado por uma Corte Federal de Nova York em 2000, fora incluído em 17 de outubro de 2001 (ONU, 1999).

A título ilustrativo, cita-se um caso um pouco mais antigo que, embora não esteja diretamente ligado ao terrorismo, está ligado ao combate contra o nazismo. Trata-se do sequestro do cidadão alemão Adolf Eichmann, por forças de segurança israelenses, em território argentino, um fato que foi divulgado, em maio de 1960, pelo governo de Israel e que gerou uma cadeia de eventos posteriores no mesmo ano: a Argentina protestou formalmente, em 8 de junho, contra o que considerou "ato ilícito em violação de um dos mais fundamentais direitos do Estado argentino"; um dia antes, o Primeiro-Ministro de Israel, Ben-Gurion, expressou sua esperança de que a Argentina colocasse consideraçóes 
morais acima das tecnicidades do Direito Internacional, relatou detalhadamente o papel que Eichmman teve como executor de judeus na Europa e expressou sua convicção de que "somente poucas pessoas no mundo não entenderiam a profunda motivação e a suprema justificativa moral desse ato" e pediu que a Argentina aceitasse "nossos mais sinceros sentimentos por todas as violaçóes de leis da República Argentina que possam ter ocorrido". Em 15 de junho, a Argentina submeteu uma queixa formal ao Conselho de Segurança da ONU, com base em violação de sua soberania estatal pelo Estado israelense, e alegou que essa conduta representa um perigoso antecedente contra a paz e a estabilidade, tendo requerido reparação por este ato. O representante da União Soviética, Arkody Sobolev, reconheceu a violação de soberania do território argentino, mas ressaltou a falha das potências ocidentais em punir os criminosos da II Guerra Mundial; Itália, Equador e França reconheceram o caráter especial do caso; o Embaixador dos EUA propôs acolhimento à queixa da Argentina, sob a condiçâo de que fosse citada a gravidade dos atos de Eichmann e a preocupação dos povos de todos os países de que ele fosse levado à justiça e, também, que constasse a esperança de que as relaçóes, tradicionalmente amigáveis entre Argentina e Israel, não restassem prejudicadas. Esse entendimento foi apoiado pela França e pelo Reino Unido e aprovado em votaçấo de 8-0, com abstençôes da União Soviética e da Polônia. A decisão do Conselho de Segurança da $\mathrm{ONU}$, todavia, não acabou com as fricçóes entre os dois países. Em 22 de julho de 1960, ocorreu a expulsão do Embaixador de Israel da Argentina, pois não ficaram definidas de modo claro quais "medidas reparatórias" seriam devidas à Argentina. Apesar de tudo, em 17 de outubro de 1960 as relaçóes diplomáticas entre Israel e Argentina voltaram ao normal. Inobstante todos os argumentos que foram levantados, do ponto de vista legal, a posiçâo de Israel era uma só, como se depreende de uma carta do Primeiro-Ministro de Israel, Ben-Gurion, escrita em 02 de junho de1960: "a justiça histórica e a honra do povo judeu exigem que esse julgamento seja feito apenas por um tribunal israelense no Estado soberano judeu”. (LISKOFSKY, 1961, p. 199-204 e 208).

O cidadão Adolf Eichmann foi, ao final, efetivamente julgado em Israel, pela Corte Distrital de Jerusalém, sob a acusação de ter praticado crimes de guerra, crimes contra a humanidade e crimes contra o povo judeu. Sua defesa argumentou que a base das acusaçóes era uma lei israelense de 1950, posterior aos fatos e que, a condenação nesta ótica, seria antiética. A Corte entendeu que o caráter "odioso" dos crimes cometidos por Eichmann afastavam o argumento da irretroatividade da lei penal. Em relação à aplicação dessa lei a fatos ocorridos fora do território de Israel, a Corte decidiu que não havia regra existente no costume internacional que proibisse a aplicação de uma lei penal a crimes cometidos por um estrangeiro fora de Israel. Por fim, sua defesa de que teria praticado "atos de Estado" não foi aceita por expressa proibição do Direito Internacional quanto a esse argumento. Eichmann foi condenado à morte por todas as acusaçôes, seu apelo foi 
rejeitado pela Suprema Corte de Israel e, minutos antes da meia-noite de 31 de maio de 1962, foi enforcado (ICD, 1962).

Interessante notar as semelhanças que existem, tanto no caso al-Liby de 2003, quanto no caso Eichmann de 1960 , no que tange à motivação da captura de civis, em territórios estrangeiros, por forças de segurança de Estados, condutas que a priori violam a soberania e da integridade territorial: a busca pela justiça, a defesa da honra do povo judeu, a lembrança dos mortos nos ataques terroristas sofridos pelos EUA, a suprema justificativa moral. Em todos os casos acima analisados, em que pesem as divergências quanto à legalidade das capturas, parece que a legitimidade daquelas condutas repousa em critérios axiológicos relacionados à ideia de uma justiça humanitária, uma moral pública internacional.

A importância que essa dimensão axiológica possui para o Direito Internacional repousa no fato de que as práticas estatais internacionais, quando geram uma opinio juris generalizada, quanto à necessidade e à obrigatoriedade de se adotar certos comportamentos, como por exemplo, a obrigação e o direito de capturar suspeitos de terrorismo em território estrangeiro, independente da autorização do Estado onde eles encontram-se, tudo isso tende a formar os chamados costumes internacionais instantâneos. A causa subjacente à formação deste tipo de costume pode ser identificada no fenômeno da indignação moral generalizada:

Recentes desenvolvimentos mostram que regras costumeiras podem vir a existir rapidamente devido à urgência de lidar com sentimentos generalizados de indignaçáo moral, relacionados a crimes cometidos em conflitos como Rwanda e Yugoslávia, que provocaram a rápida formaçáo de um conjunto de regras costumeiras relativas a crimes cometidos em conflitos internos (TREVES, 2006, $\$ 24$, tradução e grifo nossos).

Embora alguns autores rejeitem essa denominação, por considerar inapropriado falar-se de um costume "instantâneo", reconhecem, todavia, a chamada "formação rápida" de costumes, podendo aqui ser citado o caso do direito à plataforma continental, cuja origem foi um ato unilateral do governo dos EUA - a Proclamação Truman de 1945. O contexto era o de um mundo pós-guerra, com elevada demanda por gás e petróleo para reconstrução das economias destruídas e, ao perceber que a plataforma continental era rica destes recursos, o Presidente Harry Truman proclamou unilateralmente o "direito" dos EUA à exploração exclusiva desta região costeira. Houve, obviamente, um cuidado formal de assentar essa declaração em termos jurídico-legais, de modo que uma legislação doméstica foi elaborada nos EUA que, 5 anos depois, sem qualquer protesto formal ou objeção séria, passou a ser replicada por metade dos Estados costeiros daquela altura. Em 1958, esse "direito" foi codificado e transformado na Convenção de Genebra sobre Plataforma Continental, documento que passou a reconhecer internacionalmente o conceito. 
Em 1969, Corte Internacional de Justiça reconheceu que a Proclamação Truman havia criado rapidamente um direito costumeiro internacional, que vinculava coercitivamente até mesmo os Estados que não aderiram à Convenção de Genebra de 1958. Dentro dessa lógica, os ataques do 11 de setembro produziram a chamada Doutrina Bush, uma estratégia norte-americana baseada na perseguição de alvos importantes da Al Qaeda, em territórios de Estados falhados ou fracos, incapazes ou sem vontade de combater o terrorismo dentro de suas fronteiras. O amplo alcance desejado por essa estratégia produziu certa cautela na Corte Internacional de Justiça, que julgou ilegal o direito de auto-defesa contra civis, nos casos Wall, de 2004, e Congo, de 2005. Mas, "esta parece não ser a palavra final” (SCHARF, 2014, p. 335 e 338).

$\mathrm{Na}$ introdução deste paper, foram colocadas algumas questóes, notadamente que tipo de "direito" autoriza um Estado a capturar suspeitos de terrorismo em territórios estrangeiros? A nossa hipótese de trabalho aponta para um conjunto de fatores. A princípio, direitos podem ser pensados em termos de leis domésticas, convenções internacionais, jurisprudência doméstica e internacional, todas estas consideradas fontes formais do direito. Mas existem também as fontes materiais do direito, por exemplo, a influência financeira que Wall Street exerce sobre a política e a diplomacia da Casa Branca e, por conseguinte, sobre o Conselho de Segurança da ONU (órgáo detentor de certa autoridade moral internacional), além do puro e simples poder bélico de suas Forças Armadas.

Segundo um estudo publicado pela edição brasileira da Harvard Business Review, ao contrário do que pode parecer, não é tanto o setor militar que exerce influência na política norte-americana, mas sim o poder do seu setor financeiro, e esse poder é desequilibrado. $\mathrm{O}$ estudo faz uma analogia com a mecânica celeste: assim como a gravidade de um buraco negro altera a órbita de estrelas situadas anos-luz de distância, quem tem grande poder e prestígio muda o comportamento daqueles que estão ao seu redor, próximos ou distantes, de uma forma direta ou indireta. Essa influência é nítida nas doaçóes de campanha, capazes de guiar o voto de um congressista (forma direta de poder), como também nas situações em que nosso julgamento sobre os poderosos é distorcido, quando nosso pensamento é alterado (forma indireta de poder), pois "há uma tendência natural a acreditar que aqueles com poder sáo bons e justos e fazem a coisa certa. [...] A capacidade de um grupo poderoso de recompensar e punir também distorce o mercado de ideias", e isso não se trata de corrupção, no sentido criminal da palavra, pois "as crenças mudam naturalmente conforme os interesses" (MUKUNDA, 2014).

\section{Conclusões}

Com base nestas consideraçóes, é possível dizer que o "direito" de captura de civis, suspeitos de terrorismo, em territórios estrangeiros, está baseado nos tratados e 
nas convençôes internacionais, mesmo com toda a divergência que existe na sua interpretação. O sistema de normas sobre o combate ao terrorismo é complementado pelas Resoluçóes do Conselho de Segurança da ONU, que são documentos mais específicos, e que procuram eliminar as eventuais divergências contidas nos textos das convençóes. Além deste conjunto de normas de Direito Internacional, existem também as legislaçóes domésticas que legitimam a atuação das Forças Militares que, por sua vez, ao agirem no contexto de conflitos armados entre Estados e grupos terroristas, fazem nascer costumes internacionais de um modo rápido e acelerado. Todos esses documentos normativos apelam para a autoridade moral da defesa da humanidade, da paz e da segurança internacionais, além da estabilidade social e econômica.

O fenômeno do poder é complexo porque suas múltiplas formas de manifestação, igualmente importantes, entrecruzam-se para satisfazer, de modo comum, os interesses de toda a sociedade. Deste modo, o poder duro da força militar ou da coerção econômica, associado ao poder macio da diplomacia e do discurso de defesa dos direitos humanos, todas essas manifestaçóes da capacidade de um Estado ou de uma organização intergovernamental, como a ONU, de estabelecer padróes de conduta e expectativas de comportamentos futuros, estão concatenadas para alcançar o objetivo supremo da ordem internacional: a paz entre os povos. Esta paz é condição sine qua non para que as trocas comerciais aconteçam de modo estável. O comércio internacional contribui para que as riquezas circulem entre os Estados, e satisfaçam as necessidades materiais de cada nação. A paz é fundamental para que os direitos de todas as geraçóes (fundamentais, sociais, econômicos, culturais e ambientais) possam ser efetivados, pois os direitos possuem um custo financeiro. Não há direitos se não houver dinheiro para satisfazê-los. E, como visto, a paz e o comércio internacionais estão na base.

Esta é a razão pela qual o sistema normativo internacional, de combate ao terrorismo, embora apoiado em questóes axiológicas de elevado valor moral, como a defesa da dignidade humana; a busca de justiça para os inocentes mortos em atentados terroristas; ou o resgate da honra dos povos que sofreram pesadas perdas humanas; e ainda a prosperidade social e econômica global; enfim, as normas anti-terrorismo são uma extensão do sistema normativo financeiro, na medida em que as dimensóes humana e financeira se complementam. O papel que os bancos exercem em uma economia é importante para que haja capital abundante. Este capital, desde que bem utilizado, contribui para a satisfação das necessidades humanas mais fundamentais (direitos humanos, econômicos, sociais). O fato de o sistema financeiro norte-americano ter se tornado sobremaneira grande, com enorme influência sobre atos governamentais dos EUA, não invalida os esforços de combate ao terrorismo. As distorçóes sociais e econômicas, eventualmente geradas pelo tamanho do sistema financeiro norte-americano, merecem ser tratadas através de medidas de regulação aperfeiçoadas, que impeçam ex-diretores de bancos ocuparem cargos das agências reguladoras, e vice-versa. 
Considerando que o direito estará presente no "suave e natural encaixe" de uma hermenêutica cujo foco seja a defesa da liberdade - tomada essa concepção como a de justiça (SIMMONDS, 2007, p. 198); isso significa que haverá direito sempre que uma conduta, mesmo distante da legalidade, for praticada na defesa da liberdade dos povos; pois, nem sempre, condutas que obedecem estritamente a legalidade são tidas como justas, como direito. Neste sentido, apesar dos intrincados interesses que levaram à formação das normas utilizadas para legitimar aquela operação, a captura de al-Liby pelos EUA pode ser considerada um ato de defesa da liberdade dos povos, uma conduta que está conforme a justiça e o direito.

\section{Referências}

AHMED, Abdalle; SMITH, David; STEPHEN, Chris. Libya demands explanation for US 'kidnapping' of al-Qaida leader al-Liby. The Guardian, Londres, notícia online publicada em 7 out. 2013. Disponível em: <http://www.theguardian.com/ world/2013/oct/06/libya-kidnapping-citizen-us-forces-raid-somalia>. Acesso em: 30 maio 2015.

BBC. Com fama de excêntrico e de orientação nacionalista, Khadafi tirou Líbia do isolamento. BBC, Brasília, notícia online publicada em 22 fev. 2011. Disponível em: <http://www.bbc.co.uk/portuguese/noticias/2011/02/110221_perfil_khadafi_cc.shtml>. Acesso em: 30 maio 2015.

. Libya terror suspect Abu Anas al-Liby in New York court. BBC, Londres, notícia online publicada em 23 out. 2013. Disponível em: <http://www.bbc.com/news/ world-us-canada-24633617>. Acesso em: 30 maio 2015.

. Libya terror suspect Anas al-Liby dies before US trial. BBC, Londres, notícia online publicada em 3 jan. 2015. Disponível em: <http://www.bbc.com/news/world-africa-30664977>. Acesso em: 30 maio 2015.

BRONSTEIN, Scott; GRIFFIN, Drew. Self-funded and deep rooted: how ISIS makes its millions. CNN, Londres, matéria online de jornalismo investigativo, publicada em 7 out. 2014. Disponível em: <http://edition.cnn.com/2014/10/06/world/meast/isisfunding/index.html?hpt=hp_t1>. Acesso em: 05 jun. 2015.

BYERS, Michael. Custom, power and the power of rules. Cambridge: Cambridge University Press, 2001.

CARIS, Charles C.; REYNOLDS, Samuel. ISIS governance in Syria. Middle Eeast Security Report, The Institute for the Study of War, Washington - DC, v. 22, jul. 2014. p. 4-41. Disponível em: <http://www.understandingwar.org/sites/default/ files/ISIS_Governance.pdf>. Acesso em: 04 jun. 2015. 
CIJ. Armed activities on the territory of the congo. Corte Internacional de Justiça, Haia, 2005. Julgamento de 19 dez. 2005, p. 168-283. Disponível em: <http://www. icj-cij.org/docket/files/116/10455.pdf>. Acesso em: 03 jun. 2015.

. Separate opinion of judge Simma: Armed activities on the territory of the congo. Corte Internacional de Justiça, Haia, 2005a. Julgamento de 19 dez. 2005, p. 334-350. Disponível em: <http://www.icj-cij.org/docket/files/116/10467.pdf>. Acesso em: 03 jun. 2015.

CHOMSKY, Noam. Noam Chomsky on how the Iraq war birthed ISIS \& why U.S. policy undermines the fight against it. Democracy Now!, Nova York, entrevista concedida pelo professor do Massachusetts Institute of Technology, online em 02 mar. 2015. Disponível em: <http://www.democracynow.org/2015/3/2/noam_chomsky_ on_how_the_iraq>. Acesso em: 05 jun. 2015.

COCKBURN, Patrick. O novo Estado Islâmico. Lisboa: Self, 2014.

DASKAL, Jennifer; VLADECK, Stephen I. After the AUMF. Harvard National Security Journal, Boston, v. 5, 2014. Disponível em: <http://harvardnsj.org/wp-content/ uploads/2014/01/Daskal-Vladeck-Final1.pdf>. Acesso em: 04 jun. 2015.

DN. Rui Machete confirma envio de 30 militares portugueses para combater o Estado Islâmico. DN - Diário de Notícias, Lisboa, notícia online publicada em 21 abr. 2015. Disponível em: <http://www.dn.pt/politica/interior.aspx?content_id=4524422>. Acesso em: 05 jun. 2015.

DW. Libya questions US 'kidnapping' of al Qaeda suspect. DW - Deutsche Welle, Bonn, notícia online publicada em 6 out. 2013. Disponível em: <http://www.dw. de/libya-questions-us-kidnapping-of-al-qaeda-suspect/a-17138520>. Acesso em: 30 maio 2015.

GALL, Carlota. Show of Power by Libya Militia in Kidnapping. The New York Times, New York, notícia online publicada em 10 out. 2013. Disponível em: <http://www. nytimes.com/2013/10/11/world/africa/libya.html?_r=0>. Acesso em: 30 maio 2015.

HALL, John. The ISIS map of the world. The Daily Mail, Londres, notícia on line publicada em 30 jun. 2014. Disponível em: <http:/www.dailymail.co.uk/news/article-2674736/ISIS-militants-declare-formation-caliphate-Syria-Iraq-demand-Muslims-world-swear-allegiance.html>. Acesso em: 03 jun. 2015.

HARF, Mary. Daily press briefing. U.S. Department of State, Washington - DC, transcrição da conferência de imprensa ocorrida em 07 out. 2013. Disponível em: <http:// www.state.gov/r/pa/prs/dpb/2013/10/215183.htm>. Acesso em: 03 jun. 2015. 
ICD. Attorney General v. Adolf Eichmann. Supreme Court of Israel, Jerusalem, 1962. Criminal Appeal 336/61, julgamento de 29 maio 1962. International Crimes Database (ICD). Disponível em: <http://www.internationalcrimesdatabase.org/ Case/185/Eichmann/>. Acesso em: 08 jun. 2015.

LISKOFSKY, Sidney. The Eichmann case. American Jewish Yearbook, Nova York, v. 62, 1961. p. 199-208. Relato histórico do caso Eichmann. Disponível em: <http:// www.ajcarchives.org/ajc_data/files/1961_7_international.pdf>. Acesso em: 08 jun. 2015.

LITTLE, George. Statement by Pentagon Press Secretary George Little on the capture of Abu Anas al Libi. U.S. Department of Defense, Washington - DC, transcrição da notícia imediata n. 700-13, emitida pelo Pentágono em 06 out. 2013. Disponível em: <http://www.defense.gov/Releases/Release.aspx?ReleaseID=16294>. Acesso em: 03 jun. 2015.

LOS ANGELES TIMES. Terrorism and American justice. Los Angeles Times, Los Angeles, Editorial on line publicado em 08 out. 2013. Disponível em: <http://www. latimes.com/opinion/editorials/la-ed-libya-20131008-story.html>. Acesso em: 03 jun. 2015.

MODARAI, Gordon; DAVID O'Connell; KELLY, Timothy; FARRANT, James. The seizure of Abu Anas Al-Libi: an International Law assessment. International Law Studies, U.S. Naval War College, Newport, v. 89, 2013. p. 817-838. Disponível em: <https:/www.usnwc.edu/getattachment/75f620a6-aaa4-4dbb-bdf7-52ffc22b$\mathrm{d} 7 \mathrm{dd} /$ The-Seizure-of-Abu-Anas-Al-Libi--An-International-.aspx>. Acesso em: 04 jun. 2015.

MUKUNDA, Gautam. O preço do poder de Wall Street. Harvard Business Review, São Paulo, notícia on line publicada em 06 jun. 2014. Disponível em: <http://www. hbrbr.com.br/materia/o-preco-do-poder-de-wall-street>. Acesso em: 08 jun. 2015.

OBAMA, Barack. Press Conference by the President. White House, Washington - DC, transcrição da Conferência de Imprensa do Presidente dos EUA em 08 out. 2013. Disponível em: <https://www.whitehouse.gov/the-press-office/2013/10/08/pressconference-president>. Acesso em: 03 jun. 2015.

ONU. Carta das Naçóes Unidas, São Francisco: Organização das Nações Unidas, 1945. Conferência sobre Organização Internacional, 26 jun. 1945. Disponível em: <http:// unicrio.org.br/img/CartadaONU_VersoInternet.pdf>. Acesso em: 03 jun. 2015.

\section{Convenção IV relativa à Proteçáo das Pessoas Civis em Tempo de Guerra,} Genebra: Organização das Nações Unidas, 1949. Conferência para Proteção das 
Vítimas da Guerra, 12 ago. 1949. Disponível em: <https:/www.icrc.org/applic/ihl/ ihl.nsf/INTRO/380>. Acesso em: 06 jun. 2015.

Convençáo Internacional sobre a Supressão de Atentados Terroristas com Bombas, Nova York: Organização das Naçôes Unidas, 1997. Resolução n. A/ RES/52/164 adotada pela Assembleia Geral, 15 dez. 1997. Disponível em: <https://treaties.un.org/pages/ViewDetails.aspx?src=TREATY\&mtdsg_no=XVIII-9\&chapter=18\&lang=en>. Acesso em: 06 jun. 2015.

. The list established and maintained by the Resolutions 1267(1999) e 1989 (2011), Nova York: Organização das Nações Unidas, 1999. Lista do Comitê de Sanções contra Al Qaeda, Conselho de Segurança, atualizada em 22 maio 2015. Disponível: <http://www.un.org/sc/committees/1267/1267.pdf>. Acesso em: 08 jun. 2015.

. Resolution 1368 (2001), Nova York: Organização das Naçóes Unidas, 2001. Resolução S/RES/1368, Conselho de Segurança, 12 set. 2001. Disponível: <http:// daccess-dds-ny.un.org/doc/UNDOC/GEN/N01/533/82/PDF/N0153382.pdf?OpenElement>. Acesso em: 08 jun. 2015.

. Resolution 1373 (2001), Nova York: Organização das Naçóes Unidas, 2001a. Resolução S/RES/1373, Conselho de Segurança, 28 set. 2001. Disponível: <http:// daccess-dds-ny.un.org/doc/UNDOC/GEN/N01/557/43/PDF/N0155743.pdf?OpenElement>. Acesso em: 08 jun. 2015.

. Resolution 1377 (2001), Nova York: Organização das Naçóes Unidas, 2001b. Resolução S/RES/1377, Conselho de Segurança, 28 set. 2001. Disponível: <http:// daccess-dds-ny.un.org/doc/UNDOC/GEN/N01/633/01/PDF/N0163301.pdf?OpenElement>. Acesso em: 08 jun. 2015.

Report of the Special Rapporteur on extrajudicial, summary or arbitrary executions, Genebra: Organização das Nações Unidas, 2010. XIV Sessão do Conselho de Direitos Humanos, 28 maio 2010. p. 2-29. Disponível em: <http://www2. ohchr.org/english/bodies/hrcouncil/docs/14session/A.HRC.14.24.Add6.pdf>. Acesso em: 06 jun. 2015.

ROSEN, Armin. ISIS now controls a shocking percentage of Iraq and Syria. Business Insider, Nova York, notícia on line publicada em 11 jun. 2014. Disponível em: <http://www.businessinsider.com/isis-controls-shocking-percentage-of-iraq-and -syria-2014-6>. Acesso em: 05 jun. 2015.

SCHARF, Michael P. Accelerated formation of customary international law. Faculty Publications, Cleveland, paper 1167, 2014. p. 305-342. Disponível em: <http://scholarlycommons.law.case.edu/faculty_publications/1167>. Acesso em: 31 maio 2015. 
SCHMIDT, Michael, S.; SCHMITT, Eric. U.S. Officials say Libya approved Commando raids. The New York Times, New York, notícia online publicada em 9 out. 2013. Disponível em: <http://www.nytimes.com/2013/10/09/world/africa/us-officials-say-libya-approved-commando-raids.html?_r=1>. Acesso em: 30 maio 2015.

SCUS. Sosa v. Alavarez-Machain, The Supreme Court of the United States, Washington - DC, 2004. Caso 542 US 692(2004), julgamento de 29 jun. 2004. Resumo disponível em: <https://supreme.justia.com/cases/federal/us/542/692/>. Inteiro teor disponível em: < https://supreme.justia.com/cases/federal/us/542/692/opinion.html>. Acesso em: 07 jun. 2015.

SIMMONDS, Nigel. Law as a moral idea. New York: Oxford University Press, 2007.

THE BOSTON GLOBE. Libi case shows US tenacity, plus commitment to justice. The Boston Globe, Boston, Editorial on line publicado em 18 out. 2013. Disponível em: <https://www.bostonglobe.com/opinion/editorials/2013/10/18/abu-anas-libi -arraignment-shows-tenacity-commitment-justice/3u9excw6ciwCvMAw9wRPAL/ story.html? comments=all\&sort=NEWEST_CREATE_DT>. Acesso em: 03 jun. 2015.

TREVES, Tullio. Customary international law, Max Planck Encyclopedia of Public International Law, Heidelberg, nov. 2006. p. 1-25. Disponível em: <http://v880. derecho.unam.mx:8083/papime/pdf/34.pdf>. Acesso em: 08 jun. 2015.

UKSC. The Secretary of State for Foreign and Commonwealth Affairs and the Secretary of State for Defence v. Yunus Rahmatullah, The Supreme Court of the United Kingdom, London, 2012. Caso UKSC 2012/0033, julgamento de 8 jun. 2012, p. 1-38. Disponível em: <https://www.supremecourt.uk/decided-cases/docs/ UKSC_2012_0142_PressSummary.pdf>. Acesso em: 03 jun. 2015.

US CONGRESS. Joint resolution to authorize the use of United States Armed Forces against those responsible for the recent attacks launched against the United States. Congress of the United States, Washington - DC, lei de autorização do uso das Forças Armadas no combate ao terrorismo, publicada em 18 set. 2001. Disponível em: <http://www.gpo.gov/fdsys/pkg/PLAW-107publ40/pdf/PLAW-107publ40. pdf>. Acesso em: 03 jun. 2015.

WHITE HOUSE. Fact Sheet: U.S. Policy Standards and Procedures for the Use of Force in Counterterrorism Operations Outside the United States and Areas of Active Hostilities. White House, Washington - DC, política de combate ao terrorismo, publicada em 23 maio 2013. Disponível em: <https://www.whitehouse.gov/the -press-office/2013/05/23/fact-sheet-us-policy-standards-and-procedures-use-forcecounterterrorism>. Acesso em: 03 jun. 2015. 